\title{
ESSAY
}

\section{THE SHAKESPEARE GANON OF STATUTORY CONSTRUCTION}

\author{
JoHn PAUL STEVENS $\dagger$
}

The Duke of Gloucester, later King Richard the Third, begins his opening soliloquy with the famous line: "Now is the winter of our discontent." 1 The listener, who at first assumes that the word "now" refers to an unhappy winter, soon learns that war-torn England has been "[m]ade glorious by this son of York." ${ }^{\text {"2 }}$ It is now summer not winter and "[g]rim-visag'd War hath smooth'd his wrinkled" forehead. 3 Words-even a simple word like "now"-may have a meaning that is not immediately apparent.

Like the seasons, periods of war and peace come and go. As times change there is also a fluctuation in perceptions about the importance of studying humanistic values and their relation to rules of law. Nevertheless, a society that is determined and destined to remain free must find time to nourish those values. The plays and poems of William Shakespeare, sometimes collectively described as the "Shakespeare Canon," are perhaps the most stimulating and exciting works in the English language. Canons of statutory construction, in contrast, are probably the dullest materials that law students study. For these reasons, this essay includes a mixture of comment on two apparently unrelated subjects: first, the unorthodox view that Edward de Vere, the Seventeenth Earl of Oxford, is the true author of the Shakespeare Canon and, second, the utility

† Associate Justice, Supreme Court of the United States. This Essay is based on an address given as the Max Rosenn Lecture at Wilkes University in Wilkes-Barre, Pennsylvania on April 30, 1991. The Max Rosenn Lecture is an annual event honoring Senior Circuit Judge Max Rosenn, of the United States Court of Appeals for the Third Gircuit.

1 William Sharespeare, The Tragedy of Richard the THIRD act 1 , sc. 1, line 1 [hereinafter RICHARD THE THIRD] (emphasis added) (All quotations from the Shakespeare Canon in this Essay are from THE RIVERSIDE SHAAKESPEARE (G. Blakemore Evans ed., 1974) [hereinafter THE RIVERSIDE SHAKESPEARE].).

${ }^{2}$ Id. line 2. The word "son" in this line is a pun on "sun," the badge of King Edward IV. See THE RIVERSIDE SHAKESPEARE, supra note 1, at 712 n.2.

${ }^{3}$ RICHARD THE THIRD, supra note 1 , act 1 , sc. 1 , line 9. 
of certain canons of statutory construction in the search for truth and justice. Because Shakespeare's plays are typically divided into five acts, I must, of course, discuss five canons of statutory construction.

\section{ACT I}

The first canon of statutory construction is obvious: "Read the statute." The Supreme Court has reminded us over and over again that when federal judges are required to interpret acts of Congress, they must begin by reading the text of the statute. As one rather weary opinion writer has repeatedly explained, "[i]f the intent of Congress is clear, that is the end of the matter; for the court, as well as the agency, must give effect to the unambiguously expressed intent of Congress." 4 Although this proposition is universally accepted, debate often arises over the question whether there is ambiguity in the text, and if so, how far behind that text the judge may go in the quest for the author's intended meaning.

The text of the First Folio, published in 1623, seven years after William Shakespeare's death, unambiguously identifies him as the author of the Shakespeare Canon. Moreover, respected scholars are virtually unanimous in their conviction that the man from Stratfordon-Avon is the author of the masterpieces that are attributed to him. ${ }^{5}$ Nevertheless, questions that were raised by such skeptics as Mark Twain, ${ }^{6}$ Walt Whitman, ${ }^{7}$ Henry James, ${ }^{8}$ John Galsworthy, and Sigmund Freud ${ }^{9}$ still intrigue those mavericks who are persuaded that William Shakespeare is a pseudonym for an exceptionally well-educated person of noble birth who was close to the English

${ }^{4}$ Chevron v. Natural Resources Defense Council, Inc., 467 U.S. 837, 842-43 (1984); see also INS v. Cardoza-Fonseca, 480 U.S. 421, 445 n.29 (1987) (quoting Chevron).

5 See Samuel Schoenbaum, WILliam Shakespeare: A Documentary Life (1975) (presuming throughout that William Shakespeare of Stratford-on-Avon was the author of the Shakespeare Canon); see also JAMES G. MCMANAWAY, THE AUTHORSHIP OF SHAKESPEARE 37 (1962) (asserting that there is "no problem of authorship for those who have read Elizabethan drama in a setting of Elizabethan literature and history").

${ }^{6}$ See MaRK Twain, My AUtobiography 324 (1909).

7 See Horace Traubel, With Walt WhitMan at Camden 136 (1906).

${ }^{8}$ See The LetTers of HeNRY JAMES 424 (Percy Lubbock ed., 1920).

${ }^{9}$ Both Freud and Galsworthy were persuaded by the writings of John Thomas Looney (1870-1944), an English elementary schoolmaster who was one of the earliest scholars, if not the very first, to assert that Edward de Vere, the Seventeenth Earl of Oxford, was the author of the works attributed to "William Shakespeare." See Charlton OgBurN, THE MYsterious William SHakespeare 146 (1984). 
throne. Edward de Vere, the Seventeenth Earl of Oxford, was such a person. ${ }^{10}$

If we could find an original draft of one of Shakespeare's plays, or an excerpt in his own handwriting, or even a signed statement identifying himself as the author, we would have the kind of unambiguous evidence of authorship that would put an end to the matter. But the evidence of Shakespeare's handwriting that we do have is of an entirely different character. It consists of six signatures on legal documents, each suggesting that merely writing his name was a difficult task and, remarkably, that his name was Shaksper rather than Shakespeare. ${ }^{11}$ Indeed, the references to the man from Stratford in legal documents usually spell the first syllable of his name with only four letters-Shak-or sometimes Shag, or Shax-whereas the dramatist's name is consistently rendered with a long "a." For that reason, the protagonists of the Earl of Oxford's

${ }^{10}$ See id. at 146. Ogburn's comprehensive and interesting volume contains the primary current exposition of the arguments in favor of Edward de Vere's authorship. He credits Looney with the scholarship that discovered de Vere's identity. See id. at 145-46.

The authorship question has concerned writers and scholars at least since the nineteenth century. In this century, a voluminous amount of scholarship, as well as pure speculation, has been offered questioning whether Stratford's William Shakespeare wrote the plays attributed to him. The names of Francis Bacon; Christopher Marlowe; Roger Manners, the Fifth Earl of Rutland; William Stanley, the Sixth Earl of Derby; and, most commonly, Edward de Vere, the Seventeenth Earl of Oxford, have at various times been proposed as alternatives. See id. at 133-50; see also MCMANAWAY, supra note 5, at 33 (suggesting other possibilities).

The debate has even involved members of the American legal community. In February, 1959, the American Bar Association Journal published an article by lawyer Richard Bentley discussing the issue. See Richard Bentley, Elizabethan Whodunit: Who Was "William Shake-Speare"?, 45 A.B.A.J. 143 (1959). Bentley noted that the problem has both literary and evidentiary components, and that it therefore should be of interest to lawyers. See id. at 143. The article led to a flurry of letters and replyarticles in the Journal; these are collected in SHAKESPEARE CROSS-EXAMINATION (A.B.A J. ed., 1961).

On September 25, 1987, David Lloyd Kreeger, under the auspices of The American University, sponsored a debate on the authorship question between two American University law professors. The professors wrote legal "briefs," one arguing that de Vere, the Earl of Oxford, was the true author, the other taking the traditionally accepted view. Both briefs utilized the voluminous scholarship on the question. Justices William Brennan, Harry Blackmun, and I judged the debate. The panel decided that the proponents of de Vere's authorship had not met their burden of proof on the basic issue. The briefs written by the debaters, as well as several articles reflecting on the debate about Shakespearean authorship more generally, are collected in In re Shakespeare: The Authorship of Shakespeare on Trial, 37 AM. U. L. REV. 609-826 (1988).

${ }^{11}$ See OGBURN, supra note 9, at 118-21. 
cause make a point of distinguishing between Shaksper and Shakespeare. ${ }^{12}$ In this respect, they are, in effect, relying on the first canon of statutory construction. In response, the Stratfordians point out that signatures, like statutes, should be read in their contemporary context, that incorrect spelling was common in Elizabethan England, ${ }^{13}$ and that we should always be conscious of the possibility of a scrivener's error. ${ }^{14}$ This response, like the Oxfordian response to the text of the First Folio, indicates that this is a case in which we must go beyond the first canon.

\section{ACT II}

The second canon of statutory construction is much like the first: "Read the entire statute." Courts often tell us that the meaning of a particular statutory provision cannot be divined without reading the entire statute. ${ }^{15}$ Similarly, the more of Shakespeare's writing that we read, the more we learn about him. At least, that is the position that the Oxfordians advocate.

As evidence of the author's probable noble birth, they point out that all but one of his plays-The Merry Wives of Windsor-are about members of the nobility. ${ }^{16}$ The contrast between Shakespeare's characters and the commoners, such as the alchemist or the miser, about whom his contemporary Ben Jonson wrote, is striking. Even more striking is Shakespeare's repeated reference to nobility as the highest standard of excellence. The question that a lonely Hamlet asked himself was "[w]hether 'tis nobler in the mind to suffer [ $t$ ]he slings and arrows of outrageous fortune, [o] $r$ to take arms against a sea of troubles, [a]nd by opposing, end them. ${ }^{17}$ In the first act of Macbeth, when Duncan proclaimed his succession, he noted that "signs of nobleness, like stars, shall shine [o]n all deservers."18 When Mark Antony wanted to explain to Julius Caesar why there

12 See id. at 38-42.

${ }^{13}$ Indeed, it appears as though the spelling of one's name was often simply a matter of personal whimsy. See CHARLEs Hamilton, IN SEARCH OF SHAKESPEARE 45 (1985).

${ }^{14}$ See id. at 44-45.

15 See, e.g., Crandon v. United States, 494 U.S. 152, 158 (1990); K Mart Corp. v. Cartier, Inc., 486 U.S. 281, 291 (1988); Bethesda Hosp. Ass'n v. Bowen, 485 U.S. 399, 405 (1988).

${ }^{16}$ See OGBURN, supra note 9, at 240-51.

17 William Shakesfeare, The Tragedy of Hamlet, PRINCE of DeNMaRK act 3 , sc. 1, lines 56-59.

${ }^{18}$ William Shakespeare, The Tragedy of Macbeth act 1 , sc. 4, lines 41-42. 
was no reason to fear Cassius, it was enough merely to state: "He is a noble Roman, and well given. ${ }^{n 19}$ And after the conspirators had been defeated, Antony gave Brutus the highest possible praise by referring to him as "the noblest Roman of them all." 20

Shakespeare's account of the events that took place on the Ides of March may also shed light on his views about the common man. When Julius Caesar walked through the streets of Rome, the crowds greeted him with unmixed enthusiasm-obviously in favor of offering him the crown. But when he was brutally murdered in full view of countless witnesses, a few well-chosen words from Brutus, the leader of the murderous gang, were sufficient to satisfy the crowd and earn their unquestioning support. Then a few minutes later, Mark Antony's marvelous address to his "Friends, Romans, [and] countrymen" had the mob, once again, convinced that Caesar was their hero. ${ }^{21}$ Admittedly, it was a great speech, but how much respect for the common man does this sort of flip-flop-flip reveal? Perhaps the answer is found in Casca's description of the crowd's reaction when Caesar refused the crown for the third time:

[A]s he refus'd it, the rabblement howted, and clapp'd their chopp'd hands, and threw up their sweaty night-caps, and utter'd such a deal of stinking breath because Caesar refus'd the crown, that it had, almost, chok'd Caesar, for he swounded, and fell down at it; and for mine own part, I durst not laugh, for fear of opening my lips and receiving the bad air. ${ }^{22}$

Of course, the author of such a comment need not be of noble birth, but it seems appropriate to pause to take note of the fact that Edward de Vere was not an ordinary nobleman. In her biography of Queen Elizabeth, Carolly Erickson, after relating contemporary gossip about the Queen's relationship with the Earl of Leicester, had this to say about de Vere:

But it was not only Leicester who was widening his circle of conquests. Elizabeth too, it was said, was seducing handsome young men and keeping them under surveillance by her well-paid spies when they were not in amorous attendance on her. Prominent among these favorites was Edward de Vere, Earl of Oxford, a boyish, hazel-eyed young courtier whose expression combined poetic languor and aristocratic superciliousness. Oxford excelled

19 William Shakespeare, The Tragedy of Julius CaEsar act 1, sc. 2, line 197.

${ }^{20} I d$. act 5 , sc. 5 , line 68 .

21 Id. act 3 , sc. 2 , line 73 .

${ }^{22}$ Id. act 1 , sc. 2, lines 244-50. 
at those courtly graces Elizabeth admired. He was athletic and acquitted himself brilliantly in the tiltyard, dashing fearlessly, lance lowered, against any and all comers and retiring the victor despite his youth and slight build. He was an agile and energetic dancer, the ideal partner for the queen, and he had a refined ear for music and was a dextrous performer on the virginals. His poetry was unusually accomplished, and his education had given him a cultivated mind, at home with the antique authors Elizabeth knew so well. ${ }^{23}$

When Edward de Vere was twelve years old, his father died and he became a royal ward in Sir William Cecil's household. ${ }^{24}$ Cecil, also known as Lord Burghley, was the Queen's principal adviser and a master of intrigue who controlled an elaborate network of spies. ${ }^{25}$ In Hamlet, the character Polonius is unquestionably a caricature of Burghley. ${ }^{26}$ His position as advisor to the King, his physical appearance, his crafty use of Rosencrantz and Guildenstern to try to ascertain the cause of Hamlet's antic disposition, and his employment of Reynaldo to spy on his own son, Laertes, while away at school, are all characteristic of Burghley. ${ }^{27}$ One who had lived

${ }^{23}$ Carolly Erickson, The Fitst Elizabeth 267 (1983).

${ }^{24}$ See OGBURN, supra note 9, at 435-37.

${ }^{25}$ See id. at 455 .

${ }^{26}$ Shakespearean scholar A.L. Rowse writes:

There is nothing original in pointing out that Polonius is clearly based on old Lord Burghley-merely in showing how close the resemblance is in detail. Lord Treasurer and the Queen's leading minister, he had been Southhampton's guardian, whose granddaughter the young Earl would not marry and had been made to pay for it. All the Essex faction detested the politic old man, who was irremovable until his death in 1598; after that it was safe to portray him as Polonius.

Hamlet describes Polonius to his face: "old men have gray beards, their faces are wrinkles, their eyes purging thick amber and plumb tree gum ... together with most weak hams." Those who are familiar with Burghley's letters in his last years well know that they are full of his querulous complaints about his health, the weakness of his limbs, his gout, his running eyes....

One clue to Burghley's hold on power was his remarkable intelligence system. This is clearly rendered in Polonius' interview with Reynaldo, setting him to spy on his son's doings in Paris and report on them. Burghley's elder son, Thomas, had had an unsatisfactory record in France and been similarly reported on. Burghley's famous Precepts, however, were for his clever younger son, Robert-Essex's enemy: Polonius has a similar set for his son, while his perpetual moralising is Burghley all over-it drove the young men mad, all the more because the old man was all-powerful and wise, though prosy and pedestrian.

A.L. ROWSE, THE ANNOTATED SHAKESPEARE 1725-26 (1988).

27 See id. 
in his house, as de Vere did, and therefore had firsthand knowledge of Burghley's use of a spy to report on the activities of his oldest son, could well be responsible for the scene including Reynaldo-a scene that seems to have no purpose except to illuminate Polonius's-or Burghley's-character. The suspicion that there is an autobiographical element in Hamlet increases when one recognizes the parallel between Hamlet's relationship with the fair Ophelia-the daughter of Polonius-and the fact that at the age of twenty-one de Vere married Anne Cecil, the daughter of Lord Burghley. ${ }^{28}$

These are, of course, only tiny fragments from the text of the Shakespeare Canon. They are sufficient, however, to lead us to the third canon of statutory construction.

\section{ACT III}

This canon is much like the first and second, but it adds the requirement that the text be read in its contemporary context. In Cannon v. University of Chicago, ${ }^{29}$ the Supreme Court wrote that "[i]t is always appropriate to assume that our elected representatives, like other citizens, know the law ... [and that an] evaluation of congressional action [taken at a particular time] must take into account its contemporary legal context." ${ }^{30}$ The third canon therefore tells us that we should direct our attention to the sixteenth century context that produced the genius who created the Shakespeare Canon.

In those days relatively few people could read and write the English language, and those who were familiar with the leading works of Latin and Greek literature were even more scarce. Edward de Vere was such a person. In Lord Burghley's home he received instruction from the most accomplished tutors in England and later received degrees at both Cambridge and Oxford and became a member of Gray's Inn. ${ }^{31}$ As a young man he earned a reputation as a gifted writer. To the extent that literary skill is a product of education and training, de Vere's academic credentials attest to his unique qualifications. ${ }^{32}$

On the other hand, we know little about the education of William Shaksper, the man from Stratford-on-Avon. His father and

\footnotetext{
${ }^{28}$ On Edward de Vere's marriage, see OGBURN, supra note 9, at 482-84, 493.

29441 U.S. 677 (1979).

${ }^{30} I d$. at 696-99.

31 See OGBURN, supra note 9, at 432.

${ }^{32}$ See id. at $415,432$.
} 
two daughters, one of whom was married to a physician, were apparently illiterate. ${ }^{33}$ William did not attend Oxford or Cambridge and, indeed, there is no record of his attendance at any school. ${ }^{34}$ Perhaps it was the assumption that Shaksper's formal education was much too limited for him to have acquired the largest vocabulary of any author who ever lived that led other authors like Mark Twain and John Galsworthy to doubt his authorship of the Shakespeare Canon.

Knowledge of the contemporary context provides these possible answers to this concern. The illiteracy of his daughter is merely a reflection of the universal gender discrimination that permeated sixteenth century England; except for persons of noble birth, education was for males, not females. Even though his father may have been uneducated, he achieved success in business in Stratford and occupied an important public office. ${ }^{35}$ Moreover, the secondary education that was available to the sons of leading citizens in towns like Stratford-on-Avon was of a high quality. ${ }^{36}$ It is not unreasonable to assume that a good high school education is all that was needed to nurture the genius of Shakespeare to full flower.

The most telling contemporary argument, however, is found in Ben Jonson's tribute to Shakespeare in the introduction to the First Folio. Because Jonson must have been well acquainted with his leading competitor as a successful dramatist, these words take on special significance:

And though thou hadst small Latin, and less

Greek,

From thence to honour thee, I would not seek

For names; but call forth thundering

Aeschylus,

Euripides, and Sophocles...

To life again, to hear thy buskin tread,

And shake a stage .... ${ }^{37}$

${ }^{33}$ See id. at 117.

${ }^{34}$ See id. at 42, 276-79. Ogburn states that if Shaksper attended a university, "we may suspect that we should be hearing of all he had learned there . . . [but] such was not the case." Id. at 279.

${ }^{35}$ See SCHOENBAUM, supra note 5 , at $27,29-36$.

${ }^{36}$ See id. at $50-59$.

${ }^{37}$ BEN JONSON, To the Memory of My Beloved, the Author Mr. William Shakespeare: And What He Hath Left Us, in BEN JONSON: THE COMPLETE POEMS 263, 264 (George Parfitt ed., 1975). Jonson's elegy appeared in the introductory pages of the First Folio of Shakespeare's works, which was published in 1623. See THE RIVERSIDE ShareSPEARE, supra note 1, at 58, 65 (reproducing the first few pages of the First Folio). 
The emphasis is, of course, on the words "though thou hadst small Latin, and less Greek" as evidence that the author of the Shakespeare Canon was a man of limited formal education.

The Oxfordians, however, are not without a contemporary reply. They argue that the words "though thou hadst small Latin and less Greek" were ambiguous because the word "though" sometimes conveyed the meaning "even if." ${ }^{38}$ Thus, the use of this ambiguous term may have been a conspiratorial ploy to preserve the anonymity of the true author of the Canon. If you find this rejoinder a little hard to swallow, perhaps you should reflect on the ambiguity in another equally famous line by Jonson: "Drink to me, only, with thine eyes." ${ }^{39}$ Is this a plea for his lover's abstinence asking her not to drink to him with anything but her eyes? Or, more probably, is it a subtle invitation to drink only to Jonson-to save her inviting glances for him alone? Does the word "only" modify the noun "eyes" or the pronoun "me"?

\section{ACT IV}

Since ambiguity persists, we must turn to the fourth canon of statutory construction. If you are desperate, or even if you just believe it may shed some light on the issue, consult the legislative history.

The study of legislative history is itself a debatable and complex subject, including subtopics such as the respective importance of committee reports, debates on the floor of Congress, and the fact that Congress failed to enact a proposed bill that would have unambiguously resolved the point at issue. It also requires an ability to discount comments manufactured by staff members to appease lobbyists who were unable to persuade legislators to conform the statutory text to their clients' interests. As then-Justice Rehnquist observed in a dissenting opinion a few years ago:

The effort to determine congressional intent here might better be entrusted to a detective than to a judge. ... While I agree with the Court that the phrase "any other final action" may not by itself be "ambiguous," I think that what we know of the matter makes Congress' additions to $\$ 307$ (b)(1) in the Clean Air Act Technical and Conforming Amendments of 1977 no less curious than was

${ }^{38}$ See OGBURN, supra note 9, at 232-33. at 106.

39 BEN JONSON, To Celia, in BEN JONSON: ThE COMPLETE POEMS, supra note 37, 
the incident in the Silver Blaze of the dog that did nothing in the nighttime. ${ }^{40}$

For present purposes, I shall confine my analysis of the fourth canon to the Sherlock Holmes principle that sometimes the fact that a watchdog did not bark may provide a significant clue about the identity of a murderous intruder. ${ }^{41}$ The Court is sometimes skeptical about the meaning of a statute that appears to make a major change in the law when the legislative history reveals a deafening silence about any such intent.

This concern directs our attention to three items of legislative history that arguably constitute significant silence. First, where is Shakespeare's library? He must have been a voracious reader and, at least after he achieved success, could certainly have afforded to have his own library. Of course, he may have had a large library that disappeared centuries ago, but it is nevertheless of interest that there is no mention of any library, or of any books at all, in his will, and no evidence that his house in Stratford ever contained a library. ${ }^{42}$ Second, his son-in-law's detailed medical journals describing his treatment of numerous patients can be examined today at one of the museums in Stratford-on-Avon. Those journals contain no mention of the doctor's illustrious father-in-law. ${ }^{43}$ Finally-and this is the fact that is most puzzling to me, although it is discounted by historians far more learned than I-there is the seven-year period of silence that followed Shakespeare's death in 1616. Until the First Folio was published in 1623, there seems to have been no public comment in any part of England on the passing of the greatest literary genius in the country's history. ${ }^{44}$ Perhaps he did not merit a crypt in Westminster Abbey, or a eulogy penned by King James, but it does seem odd that not even a cocker spaniel or a dachshund made any noise at all when he passed from the scene.

${ }^{40}$ Harrison v. PPG Industries, Inc., 446 U.S. 578, 595-96 (1980) (Rehnquist, J., dissenting).

${ }^{41}$ Holmes discerned that the thief of a prized horse was a person known to the stable's watchdog, since the dog had not barked to awaken the boys sleeping in the stable's loft the night the horse was stolen. See ARTHUR CONAN DOYLE, Silver Blaze, in The Memorrs of Sherlock Holmes 7, 32 (Julian Symons ed., Penguin Books 1950).

42 See OGBURN, supra note 9 , at 35.

43 See Peter Levi, The Life and Times of William Shakespeare 264-66 (1988).

44 See OGBURN, supra note 9, at 11, 112. 


\section{ACT V}

The fifth canon of statutory construction requires judges to use a little common sense. This canon is expressed in various ways. For example: An interpretation that would produce an absurd result is to be avoided because it is unreasonable to believe that a legislature intended such a result. ${ }^{45}$ Both the Oxfordians and the Stratfordians believe this canon provides the answer to the authorship question. The traditional scholars consider it absurd to assume that William Shakespeare, who is known to have made a fortune as an investor in the Elizabethan theater, if not also as an actor and playwright, was just a front for a gifted author who, for reasons unknown, elected to conceal his true identity from posterity. They point out that at least one of Shakespeare's plays, The Tempest, is generally considered to have been written several years after de Vere's death in $1604,{ }^{46}$ and that the explanations for his use of a pseudonym depend on highly improbable theories of conspiracy, for at least Ben Jonson and Lord Burghley would surely have known the true identity of the author of the Shakespeare Canon. Nothing short of a royal command could have induced the author to remain anonymous.

The Oxfordians respond to the argument that it is absurd to claim that de Vere authored a play that was first published several years after his death by pointing out that there is great uncertainty about the dates when the plays were actually written. ${ }^{47}$ They also suggest that the possibility of a royal command may not be so absurd after all because Queen Elizabeth made an extraordinary grant to de Vere. Using a formula that was characteristic of special payments to members of the Secret Service, on June 26, 1586, she signed a privy seal warrant granting de Vere an annuity of one thousand pounds per year for which no accounting was to be

${ }^{45}$ See, e.g., Church of the Holy Trinity v. United States, 143 U.S. 457, 459 (1892) (if a statute frequently uses "words of general meaning," such broad language may include particular acts which, if considered within the legislation as a whole, produces "absurd results," therefore making it "unreasonable to believe that the legislator intended to include the particular act").

${ }^{46}$ See G. Blakemore Evans, Chronology and Sources, in THE RIVERSIDE SHARESPEARE, supra note 1 , at 47,56 . Evans carefully evaluates the contemporary evidence and Shakespeare's source material for each play, and estimates that The Tempest was not written before 1611 , since some of the sources used by the author were not available before September of 1610 .

${ }^{47}$ See OGBURN, supra note 9, at 382, 388. Ogburn does believe, however, that $T$ The Tempest can be dated prior to de Vere's death. See id. at 388-40. 
required. ${ }^{48}$ This was an unusually large amount at the time and the grant continued for the remaining eighteen years of de Vere's life, it having been renewed by King James. ${ }^{49}$ The Queen, it appears, may have been a member of the imaginative conspiracy and for reasons of her own may have decided to patronize a gifted dramatist, who agreed to remain anonymous while he loyally rewrote much of the early history of Great Britain. ${ }^{50}$

Whatever one may think of the fifth canon as a method of analyzing the authorship question, before I leave the subject I want to refer briefly to three cases that suggest that the fifth canon should tell us something about justice. Two of them are cases decided by William Shakespeare, whoever he may be, and the third was decided by the Supreme Court of the United States.

In the Merchant of Venice, as security for a loan of three thousand ducats, Antonio promised that if he should default, Shylock could have "a pound of his fair flesh to be taken and cut off from whatever part of his body" might please Shylock. ${ }^{51}$ As might have been predicted, Antonio did default and Shylock demanded literal performance of the terms of the bargain. In the end, however, justice was served by Portia's even more literal interpretation of the bond:

Tarry a little, there is something else.

This bond doth give thee here no jot of blood;

The words expressly are "a pound of flesh."

Take then thy bond, take thou thy pound of flesh,

But in the cutting it, if thou dost shed

One drop of Christian blood, thy lands and goods

Are by the laws of Venice confiscate

Unto the State of Venice. ${ }^{52}$

48 See BERNARD M. WARD, THE SEVENTEENTH EARL OF OXFORd 1550-1604: FROM CONTEMPORARY DOCUMENTS 255-63 (1928); see also EVA TURNER ClARK, THE MAN WHO WAS SHAKESPEARE 111 (AMS Press 1970) (1937).

${ }^{49}$ See CLARK, supra note 48 , at 113.

${ }^{50}$ See id. at 111-16. Clark credits B.M. Ward, see supra note 48 , with having uncovered the existence of the grant, and with having formulated the conspiracy theory involving Elizabeth and Edward de Vere. See id. at 111-13. On the rewriting of the history of Richard III, see, for example, JOSEPHINE TEY, THE DAUGHTER OF TIME (1951).

51 See William Sharespeare, The Merchant of Venice act 1, sc. 3, lines 1-4.

${ }^{52}$ Id. act 4, sc. 1, lines 305-12. 
Although Portia's ruling may seem somewhat technical, she was actually making a just application of the fifth canon of statutory construction.

In Measure for Measure, Claudio was sentenced to death for the crime of fornication. Since Julietta was pregnant and there was therefore no question about Claudio's guilt, and since the text of the law was perfectly clear, Angelo (who had been left in charge of law enforcement by the Duke) had no choice but to insist on literal application of the statute. Otherwise, he would:

$[\mathrm{M}]$ ake a scarecrow of the law,

Setting it up to [frighten] the birds of

prey,

And let it keep one shape, till custom make it

Their perch and not their terror. ${ }^{53}$

Nothing, of course, could be more damaging to the fabric of society than allowing the law against fornication to deteriorate into a mere scarecrow. Accordingly, it was imperative that the death penalty be administered without delay.

Fortunately, for Claudio, however, three Acts later, the allpowerful Duke reappeared and pardoned him in the nick of time. Unlike Portia in The Merchant of Venice, who served justice by using one literal reading of the bond to trump another, the Duke in Measure for Measure simply enforced the fifth canon, barely pausing to explain why any other result would have been unjust and absurd..$^{54}$

My final words are about a little known decision of the Supreme Court that averted the danger that a federal statute would turn into a toothless scarecrow. For a century and a half, the United States enjoyed the same sovereign immunity that Queen Elizabeth and King James possessed during Shakespeare's time. It was not until 1946, when Congress passed the Federal Tort Claims Act, ${ }^{55}$ waiving the defense of sovereign immunity, that the United States could be sued for damages caused by the negligence of government employees.

53 WILliam SHAKESPEARE, MEASURE FOR MEASURE act 2, sc. 1, lines 1-4.

${ }^{54}$ He simply says: "Like doth quit like, and Measure still for Measure." Id. act 5, sc. 1 , line 411 .

${ }^{55}$ Pub. L. No. 79-601, $\S \S 401-24,60$ Stat. 812, 842-47 (1946) (codified as amended at 28 U.S.C. $\S \S 2671-2680(1988)$ ). 
Eighteen years earlier, Congress had enacted the Mississippi River Flood Control Act of $1928^{56}$ to authorize a major land acquisition and construction project to control overflow and damage along the banks of the Mississippi River where it was impracticable to construct levies. A section of that Act-I shall call it the "poundof-flesh" provision-states that "[n]o liability of any kind shall attach to or rest upon the United States for any damage from or by floods or flood waters at any place. ${ }^{57}$

In the ensuing decades Congress has authorized the expenditure of countless millions of dollars to construct additional flood control projects, many of which produce artificial lakes and recreational facilities. Unfortunately, a number of people have been killed or seriously injured in those facilities. ${ }^{58}$ The case of United States $v$. James $^{59}$ arose out of a tragic accident in the reservoir behind the Millwood Dam in Arkansas. As the result of what the district court found to be worse than gross negligence, enormous underwater portals were opened without adequate warning and water-skiers were caught in the unforeseen swift current and hurled against the dam's tainter gates. ${ }^{60}$ Some drowned and others suffered permanent injuries. As other innocent victims of the negligence of federal employees had done in the past, representatives of the injured parties brought suit against the federal government under the Federal Tort Claims Act. The lower federal courts were divided on the question whether the pound-of-flesh provision enacted in 1928 in connection with the Mississippi River project should protect the United States from liability in such cases. ${ }^{61}$

As you can see, the issue is much like the ones that confronted Portia and the Italian Duke. The government based its defense on the plain language found in the text of the 1928 statute. The plaintiffs responded by arguing that the pound-of-flesh provision applied only to the Mississippi River project, that it had been impliedly repealed by the Federal Tort Claims Act which contained its own set of special defenses for the government, and that in any

${ }^{56}$ Pub. L. No. 70-391, 45 Stat. 534 (1928) (codified as amended at 33 U.S.C. $\S \S 702 \mathrm{a}-702 \mathrm{~m}, 704(1988))$.

5733 U.S.C. § 702c (1988).

58 For a recent example of such a tragedy, see Hiersche v. United States, 60 U.S.L.W. 3614 (Mar. 9, 1992) (Stevens, J., memorandum respecting denial of certiorari).

59478 U.S. 597 (1986).

${ }^{60} \mathrm{See}$ id. at 599-600.

61 See id. at $603 \&$ n.4. 
event the use of the word "damage" rather than "damages" indicated that the statute did not apply to personal injury cases. ${ }^{62}$

Although three dissenters, including the Portia that now graces our Court, would have applied a modern version of Portia's jot-ofblood argument-using a narrow interpretation of the word "damage" to trump the majority's reliance on the first canon of statutory construction ${ }^{63}$-the majority ruled in the government's favor. It relied, of course, on the first canon of statutory construction, buttressed by the principles espoused by Angelo and Shylock. ${ }^{64}$ Sadly, there was no Italian Duke to arrive on the scene in the nick of time and apply the fifth canon of statutory construction. Even more sadly, this is the kind of case-involving the average citizen rather than a nobleman who can command legions of wellarmed lobbyists-that is not apt to interest a busy Congress.

It is cases of this kind-and they appear in a variety of formsthat sometimes make me feel that now is a season of discontent. Judge Rosenn and I have lived long enough to learn, however, that like the seasons, judicial opinions about canons of statutory construction and the relation between law and justice tend to come and go. The fear that a particular law may become a toothless scarecrow, and that if judges are ever allowed to extract a single tooth from any part of a venerable code of laws, the entire code may disintegrate, is a fear that experience teaches wise judges to discount in appropriate cases. Accordingly, no matter how unhappy a particular winter may be, in due course, it is sure to be followed by other seasons that will be "[m]ade glorious by the son of York."

62 See id. at 608-12.

63 "The immunity provision absolves the United States of liability for any 'damage' by floods or floodwaters. The word 'damage' traditionally describes a harm to property (hence, 'property damage'), rather than harm to the person (usually referred to as 'personal injury')." Id. at 614 (Stevens, J., dissenting).

64 Chief Justice Rehnquist wrote:

[O]ur role is to effectuate Congress' intent, and Congress rarely speaks more plainly than it has in the provision we apply here.... We therefore follow the plain language of $\S 702 c$, a section of the 1928 Act that received careful consideration by Congress and that has remained unchanged for nearly 60 years, and hold that the Federal Government is immune from suit in this type of case.

478 U.S. at 612 (majority opinion by Rehnquist, C.J.). 
